\title{
Post-Encounter Motivation During Study Abroad
}

\section{Suzanne Bonn \\ Université du Québec à Montréal \\ Jaime Demperio \\ Université du Québec à Montréal \\ Martyna Kozlowska \\ Université du Québec à Montréal}

\section{Reference Data:}

Bonn, S., Demperio, J., \& Kozlowska, M. (2020). Post-encounter motivation during study abroad. In P. Clements, A. Krause, \& R. Gentry (Eds.), Teacher efficacy, learner agency. Tokyo: JALT. https://doi.org/10.37546/JALTPCP2019-24

Norton (2010) called for language teachers to recognize and consider a connection between a learner's motivation to learn a language and their changing identity. In the present study, we examined Japanese learners during study abroad (SA) in Canada and looked at the impact of intercultural contact on their motivation (Aubrey \& Nowlan, 2013; Clément, 1980). More specifically, we identify post-encounter motivation (PEM) as return on the investment that students make during SA and explore the ways it enhances their desire to become active participants in target language contexts. Using focus groups and questionnaires, we collected data from 2 groups ( $N=$ 13) over the course of 2 academic years and analyzed the data using qualitative content analysis. The results demonstrate the importance of PEM, reveal its salient and observable features, and offer grounds for educators to consider PEM when preparing students for SA.

Norton (2010) は、学生たちが言語を学びたいと思う気持ちと彼らのアイデンティティーの变化とのつながりについて考え 認識するよう、言語教師たちに提案した。本研究では、カナダに留学中の日本人学生たちの異文化体験が彼らのやる気に与え る影響について吟味した(Aubrey \& Nowlan, 2013; Clément, 1980)。更には、留学中の学生たちの努力と熱心さに対する見
返りとして post-encounter motivation (PEM) という概念を提示し、これが留学先社会の一員として活躍したいという彼らの 気持ちを高める過程を明らかにした。フォーカス・グループ・インタビューとアンケート調査によって、2つの集団 $(n=13)$ から2 年にわたつてデータを集め、それを質的内容分析の手法で分析した。分析の結果、PEMの重要性と特徴が明らかにされた。ま た、留学に向けて学生たちを指導する際、PEMについて考えることの大切さが示された。

or Japanese university learners of English, study abroad (SA) constitutes a substantial leap out of the Japan-specific context of an EFL classroom in which teachers are familiar with the students' homogeneous linguistic and cultural background and work around the loosely defined concept of English as a language of international communication-aligning their pedagogy with the Japanese government's discourse of kokusaika or internationalization (Kubota, 2002). Arguably, owing to an observed inwardlooking tendency of young Japanese people (see Yashima, 2013, for a discussion of uchimuki), students are operating with a vague sense of the value of English and the role it may play in their future lives. That context contrasts with SA reality wherein students delve into the domain of unfamiliar educational and social norms, new practices, and new goals (Pellegrino-Aveni, 2005; Ryan, 2009). Making the leap into the context of SA may be either a result of or a trigger for the learner's desire to make their English studies personally meaningful for their current and/or future self (Allen, 2010; Tanaka \& Ellis, 2003; Ueki \& Takeuchi, 2013). Often a decision to study abroad marks a shift in the learner's developing self-concept and their L2 user identity. Studies examining what motivates students to SA point to an internally driven need for transformations, such as attainment of a future professional stature, enhanced cultural awareness, or personal development (Schnickel, Martin, \& Maruyama, 2010).

This open-to-change attitude among Japanese learners of English was conceptualized by Yashima (2002) as international posture and is defined as "openness towards dissimilar others and a willingness to approach them as well as interest in an international vocation and in global affairs" (Yashima, 2013, p. 39). This curiosity and readiness for intercultural contact (Clément, 1980) may lead the learner to a transformation in their language identity (Clément \& Baker, 2001; Pavlenko \& Lantolf, 2000) and the conceivable 
evolution of self-concept as English-speaking actors within a global or cosmopolitan community (Yashima, 2013). In other words, drawing on Dörnyei's L2 motivational self-system of "possible selves" (Dörnyei 2005, 2009), we could construe this attitude as the ideal L2 self (representing the L2 user one would like to become) getting more defined and explicit and the ought-to L2 self (the L2 user a learner believes they ought to become) growing more attainable. Next to the two self-guides of Dörnyei's theory (ideal L2 self and ought-to L2 self), the third element, the L2 learning experience, is rooted in the immediate learning context and is defined as "the perceived quality of the learner's engagement with various aspects of the learning process" (Dörnyei, 2019, p. 20). It is "different from the first two in that it focuses on the learner's present experience, covering a range of situated, 'executive' motives related to the immediate learning environment (e.g., the impact of the L2 teacher, the curriculum, the peer group, and the experience of success)" (Dörnyei \& Ryan, 2015, p. 88).

\section{Study Abroad, L2 Learning Experience, and Post-Encounter} Motivation

The three aspects of the $\mathrm{L} 2$ motivational self-system are engaged in regulating learner motivation to different degrees at different moments of time, including the SA trajectory. On the one hand, the self-guides regulate how individuals' aspirations regarding selves determine their learning actions to motivate them to work towards achieving these selves. On the other hand, a successful engagement with the actual language learning context can be a powerful predictor of motivated behavior (Dörnyei, 2019).

These three elements are interconnected with each other and with the learner's evolving self-concept and L2 identity. They moderate the learner's attitudes towards the L2 community and the learner's fluctuating motivation to become part of it. Norton (2010) called for language teachers to recognize and consider a connection between a learner's motivation to learn a language and their evolving $\mathrm{L} 2$ selves.

In the present study, we examined the impact of intercultural contact on Japanese learners' motivation during SA. More specifically, we focused on what we identify as post-encounter motivation (PEM), a type of motivation that results from a feeling of exhilaration, accomplishment, and satisfaction after intercultural contact, and on the ways it enhances students' desire and determination to become active participants in the target language contexts.

\section{Research Questions}

This study was part of a larger research project ${ }^{1}$ examining instances of PEM before, during, and after the SA trajectory of Japanese university students in Canada, which was aimed at discovering how PEM impacts motivation and L2 self-perception. The current focus was to examine the phenomenon of PEM during SA with the following two research questions:

RQ1. What are the common observable features of PEM?

RQ2. When does PEM occur during SA?

\section{Methodology}

Participants and Setting

The participants were Japanese university students aged 20-21 years old, typically 3rdyear students in Japan. At their home universities, the students were studying English Canadian studies, and education. There were 13 student participants -11 female students and two male students-with B1-C2 English levels on the CEFR. Due to the small number of Japanese exchange students studying English at the Canadian university (known hereinafter as University X), data were collected from two sets of students: One set was from the 2017-2018 academic year (one male and five females), and the other was from the 2018-2019 academic year (one male and six females).

This study took place at a Francophone university in a large multicultural city in a French-speaking province in Canada. The SA program is 9 months long, and students take four English classes and one French class per term. Students are nominated by partner universities and are both exchange and fee-paying students. Students participate in weekly language-exchange meetings in Japanese, French, and English and join monthly sociocultural activities and excursions to practice their English.

Ethical approval was granted by University X. Student participants were recruited via email invitation by one of the researchers in the 2017-2018 academic year and by the research assistant in the 2018-2019 academic year. The students were volunteers, signed consent forms, were informed that they could discontinue the study at any time, and were assigned pseudonyms. Furthermore, participants were informed that their class grades were not affected by their participation. Any identifying information disclosed in the data was excluded and/or changed to protect the privacy of those involved. 


\section{Data Collection}

This qualitative exploratory study used focus groups and post-focus group questionnaires for data collection. For each group of students, data collection occurred during the second half of the 15-week academic session. Nunan and Bailey (2009) claimed that qualitative research "is concerned with capturing the qualities and attributes of the phenomena ... rather than with measuring or counting" (p. 7), allowing for the focus on the characteristics of PEM.

Semistructured focus group interviews were conducted with participants because this type of interview allowed for predetermined questions to be addressed as well as any follow-up questions that arose. As Nunan and Bailey (2009) stated, the "advantage of a focus group rather than an individual interview is that the informants can stimulate and be stimulated by each other" (p. 315). An interview guide, that is, a set of questions (see Appendix A), was prepared and given to the participants in advance to allow time for thinking and preparation. With the questions as a guide, open conversation was encouraged so that certain points brought up by the participants could be further discussed. Two focus groups were held simultaneously to keep the group numbers small. They were conducted in English by one of the researchers, who is the Japanese Student Coordinator, and by the research assistant. The focus group interviews were digitally recorded and approximately one hour in length. The aim of the focus group was to identify instances of PEM during SA.

To further gather "subjects' ideas, attitudes, [and] opinions" (Nunan \& Bailey, 2009, p. 126), a post-focus-group questionnaire (see Appendix B) containing five open-response items (as defined in Brown, 2009) written by the researchers was sent to participants via email shortly after the focus group. Participants wrote their responses in English. Mackey and Gass (2005) stated that open-ended questions "allow respondents to express their own thoughts and ideas in their own manner, and thus may result in more unexpected and insightful data" (p. 93). The purpose of the post-focus-group questionnaire was to determine participants' $\mathrm{L} 2$ use and learning motivation in and out of class.

\section{Data Analysis}

When doing qualitative research, analysis of data is language based (Dörnyei, 2007), and thus the audio data were put into text form. The focus group interviews were transcribed in full using Sonix, an automated transcription software that converts audio and video to text, and the transcriptions were confirmed by the research assistant. The data are presented in the participants' own words and have not been altered.
Using qualitative content analysis (Dörnyei, 2007), the texts were first read by the researchers without taking notes or highlighting. Next, a "manifest level analysis" (Dörnyei, 2007) was done in which the surface meaning of the data was identified using "descriptive coding" (Saldaña, 2013) such as a word or short phrase to summarize the text. Then, a "latent level analysis" (Dörnyei, 2007) was performed to isolate the deeper meaning of the data based on the first-stage coding. A similar process of content coding was used to code the post-focus-group questionnaires.

\section{Results}

Observable Features of Post-Encounter Motivation During Study Abroad

To answer the first research question regarding the observable features of PEM, we identified three different ways PEM was manifested: (a) recalibration of personal L2 objectives, (b) perception of learning goals as achievable, and (c) boost in confidence upon praise and encouragement.

\section{Recalibration of Personal L2 Objectives}

A recalibration of personal $\mathrm{L} 2$ objectives refers to participants' post-encounter feeling that they need to work harder to (a) make up for perceived gaps or (b) improve skills in a certain domain such as speaking, listening, reading, writing, vocabulary, or grammar. Ten instances were found in the data of encounters with classmates, teachers, university administrators, friends, and host family members. One example is from Miho who witnessed her friend from France struggling to speak in English. Miho then realized she should learn more French to better communicate with her friend. She said,

I have a friend from France. We always talk in English, and she can speak English with me, but her first language is not English but French. So sometimes, she can't remember some words in English, so she searched by her smartphone. So, sometimes, it's difficult to communicate. So that's why I thought if I can speak French, could talk with her in French fluently. So, I thought I want to learn more French.

In this case, it was not Miho's own struggles or language difficulties but her friend's struggles that motivated Miho to further her French studies.

Another example of a recalibration of language objectives comes from Shiori: 
When I talk with my friends ... about some problems in [French-speaking province] and Japan, I feel like if I could speak English more, I can explain more to them. So, I feel like I want to study more things to be able to communicate with my friends more deeply. That's the moment I feel like I wanted to study.

Shiori realized she lacked vocabulary or general knowledge allowing her to continue a conversation with friends. Her desire to have a deeper and more meaningful conversation led her to study more.

\section{Perception of Learning Goals as Achievable}

The PEM moments of a perception of learning goals as achievable occurred when participants noticed either (a) they must do what others are capable of doing or (b) they are perceived as being more proficient or capable than they think they are. Eight instances were reported after encounters with classmates, university administrators, friends, and community members. This first example comes from Taro who spoke about an in-class experience when he realized that if his classmates could do something well, then he should be able to do it too. He stated,

When I was thinking in English, I couldn't memorize a lot. But my friends in class do it very well. All of them. So. . I felt like if I study more, I can be like them. And I want to be like them.

For Taro, the PEM feeling of competition and drive moved him to improve himself linguistically.

Another example comes from Akari who described her encounter with a university librarian. She said,

So, I went to the counter and the librarian said to me 'Bonsoir.' So, I also said 'Bonsoir.' And he thought I can speak French ... so, he asked me some sentences in French, but. . . I couldn't speak very well, but I tried to reason what he said, and . . . I could understand he asked me my nationality. And so, I answered 'Oui, je suis Japonaise' [Yes, I'm Japanese]. And he said 'lalalala' [gibberish] in French (laughs), but I could catch the words and he asked me 'Why are you studying here?' So, I answered 'Je suis étudiante d'échange' [I'm an exchange student]. So, he smiled (laughs) . . . but he asked me in French many things. And after that, I was so happy because I could communicate with him. And, I thought he didn't notice I didn't speak French well, but the fact I could communicate with someone in French makes me so happy and I want to study more and more.
In this instance, Akari was perceived by the librarian as being more linguistically competent than she considered herself. The fact that she could continue a conversation in French satisfied her very much and made her want to study and use French more. She continued,

So, from that moment, I tried to speak French with my host family . . because my host father is Francophone, so he wants to speak French with me (laughs). So . . . 1 talked about it with him and he was so happy for me, also for him.

Boost in Confidence Upon Praise and Encouragement

The last observable feature of PEM during SA is an increase in student confidence after being praised or encouraged. There were 10 reported instances of this PEM, and most occurred in the context of the classroom with peers or teachers. For participants, praise pushed them to study in order to move closer to their goals. An example comes from Saki who said,

Last semester, I had a French presentation. And it was really hard for me. But it was a group presentation. And after giving presentation, my teacher gave us some comments ... only positive comments. So, I was so satisfied with it. And . . . it made me want to keep studying French.

In this case, Saki described how the positive comments from her teacher made her feel satisfied. Most participants commented how praise from classmates and teachers increased their self-confidence and self-satisfaction.

A second example comes from Akari:

There is a classmate in my class last semester, and we talk a lot in English ... And ... he asked me 'Where are you from?' and I said 'I came from Japan' and he was so surprised. 'Are you Japanese?' and I said 'Yes' because he said 'Your pronunciation is very good, so I didn't notice you're from Japan'. So, I thought 'Yes!' (laughs). Because I didn't have confidence on my English, especially speaking and pronunciation. That's why I'm taking pronunciation class now. So, I was really happy and I want to practice more.

For Akari, being praised on her pronunciation by a classmate prompted her to take a pronunciation course the following semester. 


\section{Timing of Post-Encounter Motivation During Study Abroad}

The second research question addressed the timing and setting of PEM moments during SA. PEM occurs during moments of intercultural contact, which is the interaction between different ethnolinguistic groups (Aubrey \& Nowlan, 2013). For participants, intercultural contact primarily happened with classmates, peers, teachers or supervisors, and university administrators or staff. No context seemed to be excluded as students used language to connect with their environment. The frequency and character of PEM might be, in part, a result of the unique context of the large multicultural city where the participants studied abroad. The implications of the timing of intercultural contact are discussed in the following section.

\section{Discussion and Practical Implications}

This study revealed three salient, observable features of PEM that instructors and administrators at home and host institutions can consider in order to maximize opportunities for PEM during SA.

The first observable characteristic of PEM was students' recalibration of personal L2 objectives. Students either expressed a desire to "work harder" to refine their L2 skills, or they wished to close a perceived proficiency "gap" between themselves and others. Secondly, students began to perceive their learning goals as achievable. Before their SA experience, students in this study had very limited access to speakers of other languages. In Japan, the "other" meant other Japanese English learners who share the same culture. During SA, however, there was ample opportunity for learners to compare their English skills with learners from diverse linguistic backgrounds and cultures. Perhaps this SA opportunity afforded students opportunities to measure their abilities against others who were different from those at home, which provided a fresh perspective on their own learning potential. Finally, PEM was manifested by a self-reported boost in confidence when receiving praise and encouragement.

These three features of PEM are closely linked to prior research on learner identity and motivation. A learner's identity can be affected by intercultural contact. Specifically, Yashima (2013) argued that a learner's imagined $\mathrm{L} 2$ self can feel more real due to intercultural contact. Students in our study reported that, upon interaction with others, they could recognize the way that they wanted (or needed) to improve their English and felt capable of doing so. This observation is in line with Norton-Peirce's (1995) notion that learner motivation is related to students' changing sense of self when establishing connections with others.
Our study suggests that not just any type of intercultural contact serves to enhance a learner's motivation. During SA, it is intercultural contact together with a sense of accomplishment that lead to a student's heightened interest in future learning. This combination of intercultural contact and sense of accomplishment creates the key moments of contact that motivate students to act. In response to RQ2 about the timing of PEM, teachers and administrators can facilitate student growth and development during SA by being aware of the importance of the timing of PEM. These teachable moments of intercultural contact come from interaction with local and international people inside and outside of the language classroom.

Therefore, if we accept that $\mathrm{L} 2$ learning motivation is driven by intercultural contact together with a sense of accomplishment, there are measures we suggest that instructors, administrators, and SA students can take to maximize opportunities for PEM. Home and host institutions have crucial roles to play. In preparing students for SA, we suggest that the home institution be fully familiar with the language program(s) of the host institution. Oral production and comprehension courses are vital for Japanese students in particular, so home institutions would benefit from seeking out institutions that offer comprehensive instruction in these areas. Furthermore, the home institution could maximize the potential for interpersonal encounters by informing students of extracurricular activities and community organizations available abroad. Students in this study engaged in theatre outings, cultural tours, museum exhibitions, and university activities with local students-all of which served to help students connect to their new environment. Finally, for the same reason, we recommend that home institutions offer explicit instruction on the conversational norms of the host culture. Cultures do not necessarily share conversational norms in terms of turn-taking, acceptable topics of conversation, nonverbal messages, and so on (Kramsch, 1998). For Japanese students who are unaccustomed to openly offering personal opinions or interrupting conversation, information about the host country's conversational norms could facilitate interaction and minimize confusion and frustration.

Furthermore, we know from our research that students are likely to experience changes in their self-perception as L2 users as initially reported by Norton (1997); therefore, we recommend that home institutions endeavor to sensitize students to this probability. If students are prepared to encounter these changes, they will be better equipped to recognize and integrate them when they occur.

To create moments of PEM for students after SA, we recommend that home institutions provide forums or activities to allow returnees to share their experiences. For example, group discussions or speaking activities allow returnees to communicate 
their perceived achievements and failures and their perceived changes in self-perceptions as well as their future goals. This offers opportunities for students to reframe their identities as language users and claim their position as legitimate users (Norton, 1997). As well, we suggest that home institutions facilitate contact between former and future SA students. Doing so could reinforce the sense of shared experience. More importantly perhaps, former SA students would thus have a voice as mentors and guides to future students.

Our research results suggest noteworthy implications for host institutions as well. With the goal to maximize the frequency of PEM, host institutions could establish contact with incoming students before they arrive. Having a contact person or student coordinator available to answer questions could be extremely beneficial. This person could serve as a crucial link between the students and life in the new environment.

We also recommend host university staff (i.e., instructors and program administrators) be sensitized to the cultural differences of Japanese students. Examples of notable differences may include classroom pedagogies, expectations of instructors and students, conversational norms, and the balance of school, work, and personal life. Likewise, the host institution could emhance Japanese students' awareness of their evolving L2 selves by organizing focus groups, discussions, and self-reflection journal writing assignments.

Overall, we have found the following to be of greatest help and importance to Japanese students: (a) participation in activities (formal and informal) that promote intercultural contact and (b) positive reinforcement and feedback from instructors and other sources including staff, host family members, and peers. We believe that Dörnyei's third element of the L2 motivational self-system, the L2 learning experience, plays a crucial role in helping to create PEM moments.

\section{Limitations and Future Research}

We recognize the limitations of the current study. A larger sampling would allow for more generalizable results and could reveal new information. In addition, we could triangulate data collected over more sessions with different students, and we could have richer data if we added journal reflections to the data collection methods. Furthermore, we could collect data at various stages of the SA experience versus only toward the end. Moreover, students self-reported in English only. If they had reported in their native language, the data may have taken on a different flavor. The data will become more robust as our research continues and our participant numbers continue to grow, making it more accurate and, thus, generalizable. Finally, this research concerns the perceptions, particularities, and needs of Japanese students studying in a North American context.
Results using similar numbers and data collection tools could vary with different student populations and learning environments. This could reveal other sources and characteristics of PEM. In future research, we will examine the significance of PEM throughout the full SA trajectory (i.e., before, during, and after SA) and establish whether PEM has any lasting effects.

\section{Conclusion}

Our study was aimed at identifying the salient and observable features of post-encounter motivation (PEM) in study abroad (SA). Student motivation is fluid, and SA is a particular context where motivation is subject to new triggers for motivated learning. One of those triggers is PEM, which seems to have a positive impact on students' learning behavior. There are particular characteristics of and contexts for PEM. Recognizing the characteristics and providing these contexts can help instructors and administrations to maximize L2 motivation during the entire SA trajectory. The research is still in its early phases; however, there is a clear indication that PEM does play a significant role in L2 acquisition.

\section{Notes}

1. See References for paper presentations by the three researchers (Bonn, Demperio, \& Kozlowska, 2018, November; 2019, June; 2019, November; 2021, June). These presentations describe research related to this study.

\section{Bio Data}

Suzanne Bonn is the Japanese Student Coordinator at the Université du Québec à Montréal in Montreal, Quebec, Canada. She has a PhD in applied linguistics from Aston University (U.K.) and has taught in the United States, Germany, Japan, and Canada for 25 years. She taught at universities in Nagoya for nearly 13 years and now teaches and coordinates language programs in Montreal. Her research interests are study abroad and teacher education. <bonn.suzanne@uqam.ca>

Jaime Demperio is an English language instructor at the Université du Québec à Montréal. They obtained an MA in linguistics from Syracuse University in New York. They teach reading, writing, interpersonal communication skills, and courses concerning the interplay of language and culture. Their research interests concern identity and language learning. < demperio.jaime@uqam.ca> 
Martyna Kozlowska is an English language instructor at the Université du Québec à Montréal. She obtained a PhD in linguistics from McGill University, Montreal, Canada. She teaches grammar, syntax, and critical reading at École de langues, UQAM. Her research interests lie in the domain of generative approaches to SLA as well as questions of identity and L2 learning. <kozlowska.martyna@uqam.ca>

\section{References}

Allen, H. W. (2010). Language-learning motivation during short-term study abroad: An activity theory perspective. Foreign Language Annals, 43, 27-49.

https://doi.org/10.1111/j.1944-9720.2010.01058.x

Aubrey, S., \& Nowlan, A. G. P. (2013). Effect of intercultural contact on L2 motivation: A comparative study. In M. T. Apple, D. Da Silva, \& T. Fellner (Eds.), Language learning motivation in Japan (pp. 129-152). Bristol, England: Multilingual Matters.

Bonn, S., Demperio J., \& Kozlowska, M. (2018, November). Japanese student investment in study abroad. Paper presented at the annual Japan Association for Language Teaching (JALT) Conference, Shizuoka, Japan.

Bonn, S., Demperio, J., \& Kozlowska, M. (2019, June). Post-encounter motivation: Investigating Japanese students' sense of L2 self during study abroad. Paper presented at the annual Canadian Association of Applied Linguistics (ACLA-CAAL) Conference, Vancouver, Canada.

Bonn, S., Demperio, J., \& Kozlowska, M. (2019, November). Post-encounter motivation during study abroad. Paper presented at the annual Japan Association for Language Teaching (JALT) Conference, Nagoya, Japan.

Bonn, S., Demperio, J., \& Kozlowska, M. (2021, June). Post-encounter motivation during study abroad: The role of intercultural contact. Paper to be presented at the annual Psychology of Language Learning Conference, Sydney, Canada.

Brown, J. D. (2009). Open-response items in questionnaires. In J. Heigham \& R. A. Croker (Eds.) Qualitative research in applied linguistics: A practical introduction (pp. 200-219). Hampshire, England: Palgrave Macmillan.

Clément, R. (1980). Ethnicity, contact and communicative competence in a second language. In $\mathrm{H}$ Giles, W. P. Robinson, \& P. Smith (Eds.), Language: Social psychological perspectives (pp. 147-154) Oxford, England: Pergamon Press.

Clément, R., \& Baker, S. C. (2001). Measuring social aspects of L2 acquisition and use: Social characteristics and administration (Tech. Rep.). Ottawa, Canada: School of Psychology, University of Ottawa.

Dörnyei, Z. (2005). The psychology of the language learner: Individual differences in second language acquisition. Mahwah, NJ: Erlbaum.
Dörnyei, Z. (2007). Research methods in applied linguistics. Oxford, England: Oxford University Press.

Dörnyei, Z. (2009). The L2 motivational self system. In Z. Dörnyei \& E. Ushioda (Eds.), Motivation language identity and the L2 self (pp. 9-42). Bristol, England: Multilingual Matters.

Dörnyei, Z. (2019). Towards a better understanding of the L2 learning experience, the Cinderella of the L2 motivational self system. Studies in Second Language Learning and Teaching, 9(1), 19-30. https://doi.org/10.14746/ssllt.2019.9.1.2

Dörnyei, Z., \& Ryan S. (2015). The psychology of the language learner revisited. New York, NY: Routledge.

Kramsch, C. J. (1998). Language and culture. Oxford, England: Oxford University Press.

Kubota, R. (2002). The impact of globalization on language teaching in Japan. In D. Block \& D. Cameron (Eds.), Globalization and language teaching (pp.13-28). London, England: Routledge.

Mackey, A., \& Gass, S. (2005). Second language research: Methodology and design. Mahwah, NJ: Erlbaum.

Norton, B. (1997). Language, identity, and the ownership of English [Introduction, Special Issue]. TESOL Quarterly, 31(3), 409-429. https://doi.org/10.2307/3587831

Norton, B. (2010). Language and identity. In N. Hornberger \& S. McKay (Eds.), Sociolinguistics and language education (pp. 349-369). Bristol, England: Multilingual Matters.

Norton-Peirce, B. (1995). Social identity, investment, and language learning. TESOL Quarterly, 29(1), 9-31. https://doi.org/10.2307/3587803

Nunan, D., \& Bailey, K. (2009). Exploring second language classroom research: A comprehensive guide. Boston, MA: Heinle.

Pavlenko, A., \& Lantolf, J. P. (2000). Second language learning as participation and the (re) construction of selves. In J. P. Lantolf (Ed.), Sociocultural theory and second language learning (pp. 155-177). Oxford, England: Oxford University Press.

Pellegrino-Aveni, V. A. (2005). Study abroad and second language use: Constructing the self. Cambridge, England: Cambridge University Press.

Ryan, S. (2009). Ambivalence and commitment, liberation and challenge: Investigating the attitudes of young Japanese people towards the learning of English. Journal of Multilingual and Multicultural Development, 30(5), 405-420. https://doi.org/10.1080/01434630902928447

Saldaña, J. (2013). The coding manual for qualitative researchers (2nd ed.). London, England: Sage.

Schnickel, J., Martin, R., \& Maruyama, Y. (2010). Perspectives on studying abroad: Motivations and challenges. Language, Culture, and Communication, 2, 103-120.

Tanaka, K., \& Ellis, R. (2003). Study abroad, language proficiency, and learner beliefs about language learning. JALT Journal, 25, 63-85. https://doi.org/10.37546/JALTJJ25.1-3 
Ueki, M., \& Takeuchi, O. (2013). Forming a clearer image of the ideal L2 self: The L2 motivational self system and learner autonomy in a Japanese EFL context. Innovation in Language Learning and Teaching, 7(3), 238-252. https://doi.org/10.1080/17501229.2013.836205

Yashima, T. (2002). Willingness to communicate in a second language: The Japanese EFL context. The Modern Language Journal, 86, 54-66. https://doi.org/10.1111/1540-4781.00136

Yashima, T. (2013). Imagined L2 selves and motivation for intercultural communication. In M. T. Apple, D. Da Silva, \& T. Fellner (Eds.), Language learning motivation in Japan (pp. 35-53). Bristol, England: Multilingual Matters.

\section{Appendix A}

\section{Focus Group Questions}

1. Tell us about a time in your life when you felt a sense of accomplishment (or motivation, excitement, inspiration, or satisfaction-a sense of believing in yourself and your abilities) which made you want to learn something more. (Example:

Went to a music concert and decided to learn to play the guitar. Went to a play and decided to read the book the play is based on.)

2. Did this sense of accomplishment happen to you in a school context (high school, university in Japan, studying English in university in Japan, short-term study abroad)? Describe. How did you feel? What did you do to follow-up on those feelings?

3. Did this sense of accomplishment happen to you sometime during your study abroad at University X? Describe. How did you feel? What did you do to follow-up on those feelings?

4. What moments in class made you want to learn English more deeply? French?

5. What moments out of class made you want to learn English more deeply? French?

\section{Appendix B}

\section{Post-Focus-Group Questionnaire}

1. Describe how you use English and French in the following contexts.

a. in class (e.g., listen only, participate actively, participate only when asked a question, etc.)

English:

French: b. out of class (e.g., where you live, with friends, with strangers, when travelling, etc.)

English:

French:

2. Have any of the following activities increased your motivation to learn English? Why or why not? (Note: If you didn't attend, please write "N/A" = not applicable.)

a. PROFSS talks (by guest speakers)

b. ANG Theatre Society Outings (pre-show workshop, play)

c. English Language Help Desk (in French: Centre d'Aide en Langues Modernes, CALM)

d. Activities/outings/trips with Japanese Student Coordinator

3. What in-class activity most helped you feel more willing to use/learn English/ French at University X?

English:

French:

4. What out-of-class activity most helped you feel more willing to use/learn English/ French in Name of Canadian City?

English:

French: 